\title{
Development of Learning Materials with Visualization, Auditory, Kinesthetic (VAK) Model to Improve Students' Mathematics Reasoning Ability and Self-Confidence
}

\author{
Milda Rizky Novriani* $\quad$ Elmanani Simamora Izwita Dewi \\ Department of Mathematics, Science Faculty, State University of Medan, Jl. William Iskandar Ps.V, Kenangan \\ Baru, Sumatera Utara, Indonesia
}

\begin{abstract}
This study aims to produce: 1) a valid learning materials developed with the VAK model; 2) practical learning materials developed with the VAK model; 3) effective learning materials developed with the VAK model; 4) improvement of students' mathematical reasoning abilities taught using learning materials developed with the VAK model; 5) improvement of students' self-confidence is taught using learning materials developed with the VAK model. This research is a development study using a 4-D model. From the results of trial I, trial II and disseminate stage obtained : 1) learning material developed with the VAK model have met valid criteria; 2) learning material developed with the VAK model meet practical criteria in terms of: a) expert judgment; and b) observations of the implementation of learning material; 3) learning material developed with the VAK model meet effective criteria in term of: a) classical student completeness has been achieved in trial II of $88,57 \%$ and the disseminate stage of $91,43 \%$; b) achievement of learning objectives for each item c.) positive student responses to learning materials; d) learning time does not exceed normal learning time; 4) students' mathematical reasoning abilities using learning materials developed with the VAK model increased, in terms of N-Gain scores in trial I by 0.29 increased to 0.34 in trial II and increased to 0.57 at the disseminate stage; 5) Self-confidence of student using learning materials developed with the VAK model increased, in terms of The average result of the self-confidence questionnaire in trial I by 75.91 increased to 78.77 in trial II and increased to 79.97 in disseminate stage.
\end{abstract}

Keywords: VAK, mathematic reasoning ability, self-confidence

DOI: $10.7176 / \mathrm{JEP} / 10-29-11$

Publication date:October $31^{\text {st }} 2019$

\section{Introduction}

Education has a close relationship with learning in schools to achieve a change. Through education, changes in improving the quality of education are very large which is one of the focuses of development in the field of education to face future challenges. An education is said to be of good quality if the education process takes place effectively and produces human resources that are beneficial to the nation and state. Education involves all experiences that an individual acquires inside or outside the school (Turkkahraman 2012).

Changes in improving the quality of education related to science and technology. Mathematics is one of the fields of study that supports the development of science and technology. Mathematics is knowledge loaded with materials which can trigger the development of thinking ability particularly reasoning ability (Rohana 2015). In addition, mathematical reasoning refers to the ability to formulate and represent problems given by mathematics, and to explain and justify solutions or arguments (Kilpatrick et al. 2001).

But in reality, many times students learn mathematical concepts without understanding them because some teachers teach them procedures without connections to their contextual experiences (Makonye 2014). Therefore, the low value of mathematics is due to several things, among others, there is an error of understanding about the problem, an error that occurs in the results and in the process of solving the problem, including the calculation in the form of multiplication, division, addition and subtraction (Islamiyah et al. 2018). Correspondingly, most students can not model the problem in the form of proportional equations correctly, students can not identify the relationship in the multiplication problems of proportional reasoning and low students' reasoning ability is caused by passive students in the learning process, students are not independent in building knowledge and students are not trained to develop proportional reasoning abilities (Misnanti et al. 2017). Based on preliminary observations made, the researcher gave a question of mathematical reasoning ability tests. The indicators of mathematical reasoning ability in this study are: (1) submit allegations; (2) check the validity of an argument; (3) draw conclusions, compile evidence, provide reasons or evidence for the correctness of the solution; and (4) draw conclusions from statements.

From the analysis result of the answers given, students have not been able to understand the concept correctly so that the allegations given do not lead to the answers needed from the problem, students have not been able to make in the mathematical model and provide an explanation to the proper form of venn diagrams so students have not been able to check the validity. In addition, students does not have ideas in solving problems by making examples so students have not been able to compile evidence and students have not been able to provide an 
explanation of the conclusions obtained. This shows that the students' mathematical reasoning ability is still low. Therefore, to make thinking and reasoning to be one of the corner-stone on the learning process and activities in school, it needs the commitment of all of mathematics teachers to focus students 'attention and prior knowledge to essential aspects for supporting depth and meaningful learning, enhance students' thinking ability through pose question techniques, apply knowledge learned to real situations, take benefit of students' learning experiences, engage students more in the process of teaching and learning, and cultivate students' conceptual understanding for supporting meaningful learning without laying on rote learning only (Napitupulu et al. 2016).

In addition to mathematical reasoning ability, the ability in other aspects that are affective namely selfconfidence in problems solving related to mathematics. Confidence is the ability to take appropriate and effective actions in any situation, however challenging it appears to you or others (Burton \& Platts 2006). Self-confidence is built because the students have natural experience in the process of achieving learning goals and learning processes (Anwar 2016). Low self-confidence is a barrier to developing the potential it has (Juliana \& Surya 2017). Correspondingly, An individual who lacks in self-confidence will most probably have a negative value towards the course and the classroom (Tuncel 2015). Self-confidence is critical to effective performance in the workplace and is the source of assertiveness, which is fully representing yourself to others (Reddy 2014).

Based on the results of researcher interviews with Mathematics VIII junior high school teachers that students' self-confidence is still relatively low, seen from the students who are passive when given questions and only waiting for the answers from their friends. Students are not confident in expressing their opinions or answers to math problems that they are working on. Students lack confidence when asked to solve the problems on the board. This indicates that students' self-confidence is still low, and their lack of confidence to express ideas and abilities they have to complete the problem exercises that been given.

Learning material are a number of materials, media, instructions and guidelines that will be used in the learning process (Suhadi 2007). The learning material developed by the teacher should be produce quality products in order to create learning that actively engages students, learns meaningfully and is able to build students' mathematical abilities. But in the reality that occurs in the field based on the observations of researcher like most teachers consider the learning device only as a condition of administrative completeness, without regard to the aspects of feasibility, practicality or effectiveness of the learning material that have been made. The learning material that will be made must also refer to a learning model so that the device developed into a single unit that is complementary and focused on the objectives to be achieved. An approach or learning model is needed which is capable to accommodate mathematical thinking ability of student teacher particularly mathematical reasoning (Rohana 2015).

Responding to the problem as described above, it is necessary to improve efforts in choosing learning that can change the paradigm by implementing certain learning models. In this case the researcher chose to use the Visualization, Auditory, Kinesthetic (VAK) learning model. Learning model Visualization, Auditory, Kinesthetic (VAK) helps students to train and develop their own personal potential, provide direct experience, able to involve students maximally in finding and understanding a concept through physical activities such as demonstrations, experiments, observations, and active discussion (Saputri \& Sari 2017).

\section{Literature Review}

\subsection{Reasoning and Mathematical Reasoning Ability}

Reasoning is a process of drawing conclusions from one or more propositions (Surajiyo 2010). Reasoning is an activity or process, or think ability to take a conclusion or make a correct new statements (Rizqi \& Surya 2017). In line with Zulfa, Yerizon and Amalita (2014) which states that reasoning is an activity, a process or an activity of thinking to draw conclusions or making new statements based on statements whose truth has been proven before and draw conclusions by linking existing facts. Based on this opinion, it can be concluded that reasoning is an activity of the thinking process in drawing conclusions or making new statements whose truth has been proven by connecting with known facts to a conclusion.

The ability of mathematical reasoning is the ability to connect mathematical ideas or objects, make, investigate and evaluate mathematical conjectures, and develop mathematical arguments and evidence to convince themselves and others that the allegations raised are true (Subanindro 2012). The ability of mathematical reasoning helps students in concluding and proving a statement, building new ideas, until solving problems in mathematics. Therefore, mathematical reasoning ability must always be familiarized and developed in every mathematics learning (Sumartini 2015). So it can be concluded that mathematical reasoning is a process of thinking that connects mathematical ideas or objects is done by drawing a conclusion about a mathematical problem and can be explain or give reasons for a solution.

\subsection{Self-Confidence}

Self-confidence is an attitude of being confident in one's own abilities and seeing yourself as a whole person by referring to self-concept (Lesari \& Yudhanegara 2015). Self-confidence is not inherited or innate nature but is 
derived from life experience and can be educated and added by educators with various efforts to shape and improve self-confidence (Sihotang et al. 2017). The self-confidence indicators are: (1) believe in one's own abilities; (2) acting independently in making decisions; (3) have a positive self-concept; and (4) dare to express opinions (Lesari \& Yudhanegara 2015).

The main form of student self-confidence in learning mathematics is student interaction both with teachers and with fellow students (Preston in Nurqolbiah 2016). From the direct interaction with other people will get information about themselves and can assess themselves when compared with others. Someone will be able to understand themselves and will know who they are and will develop into self-confidence. From some of the meanings above, it can be concluded that self-confidence is one's own belief in the ability possessed to shape understanding and solve the problems it faces.

\subsection{Visualization, Auditory, Kinesthetic (VAK) Learning Model}

Visualization, Auditory, Kinesthetic (VAK) learning model is a learning model that optimizes the three learning modalities to make the student feel comfortable (Shoimin 2016). Visualization, Auditory, Kinesthetic (VAK) learning model is a child of the quantum learning model that is principled to make the learning situation more comfortable and promises success for its learners in the future. The learning steps using the Visualization, Auditory, Kinesthetic (VAK) learning model are: (1) the preparatory stage (preliminary activities); (2) delivery phase (core activities in exploration), (3) training stage (core activities on elaboration), and (4) stage of performance display (core activities on confirmation).

\subsection{Learning materials}

Learning devices are material or equipment to carry out processes that enable educators and students to carry out learning activities (Zuhdan et al. 2011). The reasons why teachers need to develop learning material include the availability of materials according to curriculum demands, target characteristics, and demands for problem solving learning (Depdiknas 2008). In this case the learning materials that will be developed are the learning implementation plan, teacher book, student book, student activity sheet, mathematical reasoning ability tests, and student self-confidence questionnaire.

\section{Research Methods}

This research includes development research. This study uses the Thiagarajan et al development model (1974) which is often referred to as $4 \mathrm{D}$, includes 4 steps namely define, design, develop and disseminate. This research was carried out at SMP 24 Medan which is one of the Junior High Schools in Medan, North Sumatra, Indonesia. The subjects in this study were students of class VIII of SMP 24 Medan 2018/2019 school year. The object in this study is a learning material developed using the Visualization, Auditory, Kinesthetic (VAK) model on the subject matter of relations and functions, namely learning implementation plans, teacher book, student book, student activity sheet, reasoning ability tests mathematical and student self-confidence questionnaire.

The instruments used in this study were tests and questionnaires. Tests are used to measure mathematical reasoning abilities and questionnaires are used to see students' responses. Practical criteria can be seen from the expert's assessment of the developed learning material that can be used with little or no revision, and from observations of the implementation of learning material in class categories good or very good. Furthermore, the effectiveness criteria of learning material can be seen from: (1) Completion of classical learning students at least $85 \%$ of students who get a mathematical reasoning ability test have scored $\geq 71$; (2) the achievement of learning objectives at least $75 \%$ of students have reasoning abilities; (3) At least $80 \%$ of students respond positively to the learning material components developed; and (4) The study time used does not exceed the usual study time (Modification from Herman 2012; Hasratuddin 2018).

To analyze the improvement of students' mathematical reasoning abilities, data obtained from the results of pre-test and post-test students. Improving students' mathematical reasoning abilities can be obtained from normalized gain index data by Hake (1999), as follows:

$$
\text { Indeks Gain Ternormalisasi }=\frac{\text { posttest }- \text { pretest }}{\max \text { imum possible score }- \text { pretest }}
$$

with the normalized gain index criteria $(\mathrm{g})$ shown in the following table:

\begin{tabular}{ll}
\multicolumn{2}{l}{ Table 1. The Normalized Gain Score Criteria } \\
\hline Gain score & Category \\
\hline $\mathrm{g}>0.7$ & High \\
\hline $0.3<\mathrm{g} \leq 0.7$ & Medium \\
\hline $\mathrm{g} \leq 0.3$ & Low \\
\hline
\end{tabular}

While the achievement measure used in the student's self-confidence questionnaire was taken based on the Likert 
scale. To determine student answer scores, we applied scoring guidelines on the Likert scale for each statement, namely the score for each statement was 1 (strongly disagree), 2 (disagree), 3 (agree), and 4 (strongly agree).

\section{Results \& Discussion}

\subsection{The Description of Learning Materials Development Stage}

In this research, learning materials development with the Visualization, Auditory, Kinesthetic (VAK) model have met the criteria of valid, practicality and effectiveness in trial II and the disseminate. The results of the development learning materials using the Thiagarajan (1974) 4-D model are described as following.

4.1.1 Stage 1-Define

Based on the observations in SMP 24 Medan found several weaknesses in the learning material used by teachers, the preparation of the lesson plan did not include the learning model used and in the learning activities there was no visible feedback on the activities carried out by students and teachers, subject matter in books used by teachers and students are still in general not adjusted to the needs and the questions are still not enough to support the achievement of mathematical reasoning, and the teacher does not use student activity sheet as a support for learning activities but only uses exercises that are contained in books. Furthermore, in the learning process the teacher still uses a conventional approach, and the teacher is also not accustomed to giving confidence to students through motivational words so that students have self-confidence in solving the given problem.

4.1.2 Stage 2-Design

This stage produced an initial draft of the lesson plans for 3 meetings, student book, student activity sheet, mathematics reasoning ability test, and students' self-confidence questionnaire. All result at this design stage is called draft I.

4.1.3 Stage 3-Develop

At this stage, the revised draft I based on the experts is then trialled. The aim is to see the weaknesses in draft I so that they can be revised and perfect the learning material developed. The results of expert validation in the form of content validity assessments indicate that all learning material meet valid criteria, with a total average validation value of the lesson plans is 4.57 , teacher book is 4.61 , student book is 4.61 , and student activity sheet is 4.56 . All the items of mathematical reasoning ability tests and student self-confidence questionnaires meet the validity and reliability criteria. Instrument reliability is used to determine test results. After the calculation, the reliability test of mathematical reasoning ability is 0.606 (high category) and the self-confidence questionnaire is 0.959 (very high category).

After the learning device developed meets the validity criteria, the learning device in the form of draft II was tested on the subject class and research site, namely SMP Negeri 24 Medan, hereinafter referred to as the trial I. Based on the results of the analysis data of trial I, it was found that the learning device developed does not meet all the effectiveness criteria, so improvements are made to produce learning material that meet all the established effectiveness criteria. The revision was based on findings from the weaknesses of the learning material in trial I, namely for the lesson plan related to the allocation of learning time, as well as on student book and worksheet related to the material being taught. After the revision is complete, the trial II is conducted to determine the effectiveness of the learning device, as well as to improve students' mathematical reasoning abilities and achievement of self-confidence.

\subsubsection{Stage 4-Disseminate}

This stage is carried out by retrying the learning device at the research site, namely in class VIII-F with a total of 35 students. The test is conducted 3 times in accordance with the lesson plan that was developed with the aim of measuring the quality accuracy of the learning material with the Visualization, Auditory, Kinesthetic (VAK) model.

\subsection{Result of Trial I}

Based on the results of the data analysis of trial I, it was found that the learning material developed were not yet effective, because there were still several indicators of effectiveness that had not been achieved. The results of classical completeness in the mathematical reasoning ability of students in the trial I, namely at pretest $51.43 \%$ while posttest $77.14 \%$, this shows that students have not met the classical completeness criteria. In addition, the achievement of learning objectives in the trial I, namely the results of the posttest mathematical reasoning ability has been achieved for item 1 of 85.71 and item 3 of 79.29 while for item 2 of 67.14 and item 4 of 72.14 , this shows that the learning objectives have not been achieved.

Indicators of effectiveness that have been fulfilled in trial I are positive student responses to learning material based on the Visualization, Auditory, Kinesthetic (VAK) model with an average percentage of total positive student responses in trial I is $88.40 \%$, while achieving time learning, the study time used is the same as regular study time.

Improvement of students' mathematical reasoning abilities in the trial I is seen through the $\mathrm{N}$-gain from the results of the pretest and posttest mathematical reasoning abilities in the trial I. From the data obtained by students who received an $\mathrm{N}$-gain score in the range $\mathrm{g}>0.7$ or experienced an increase in mathematical reasoning abilities 
with the category of "High" as much as 1 student, students who have increased mathematical reasoning ability with the category "Medium" or get an $\mathrm{N}$-gain score of $0.3<\mathrm{g} \leq 0.7$ as many as 15 students and students who have increased mathematical reasoning ability with a category "Low" or get an N-gain score of $\mathrm{g} \leq 0.3$ totaling 19 students. While the average $\mathrm{N}$-gain in the first try was 0.29 in the "low" category. Based on the data obtained on the achievement of self-confidence of the students in the trial I the most dominant was the high and very high categories, which showed that students were trial I had high self-confidence.

\subsection{Result of Trial II}

Based on the results of the analysis of trial II data, it was found that the learning material developed were effective based on indicators of effectiveness that had been achieved. The classical completeness results of students' mathematical reasoning ability in the trial II, namely at the pretest $65.71 \%$ while the posttest $88.57 \%$. This shows that students have met the classical completeness criteria. In addition, the achievement of learning objectives in trial II, namely the results of the posttest mathematical reasoning ability has been achieved for item 1 of 86.43 , item 2 of 87.14 , item 3 of 82.14 and item 4 of 77.14 This shows that the learning objectives have been achieved. Likewise, the average percentage of total positive responses of students in trial II was $92.17 \%$, so it can be concluded that student responses to components and learning activities were very positive. Furthermore, the learning time used is in accordance with specified criteria.

Improved students' mathematical reasoning ability from data obtained in trial II students who received Ngain scores in the range $\mathrm{g}>0.7$ or experienced an increase in mathematical reasoning abilities with the category of "High" by 2 students, there were 17 students experiencing the increased mathematical reasoning abilities with the category "Medium" or get an $\mathrm{N}$-gain score in the range of $0.3<\mathrm{g} \leq 0.7$ and 16 students experienced an increase in mathematical reasoning abilities in the "Low" category. "Or get an $\mathrm{N}$-gain score of $\mathrm{g} \leq 0.3$. The average total in trial II was obtained 0.34 in the medium category.

Based on the data obtained on the achievement of students' self-confidence in the trial II that most dominates is the high and very high categories, which shows that students in the trial II have high self-confidence.

\subsection{Result of Disseminate Stage}

Based on the results of data analysis at the disseminate stage, it was found that the learning material developed were already effective. The classical completeness results of students' mathematical reasoning ability at this stage, namely at $77.14 \%$ pretest while posttest $91.43 \%$. This shows that students have met the classical completeness criteria. In addition, the achievement of learning objectives at the disseminate stage, namely the results of the posttest mathematical reasoning ability has been reached for item 1 of 86.43 , item 2 of 95.00 , item 3 of 86.43 and item 4 of 87.14 . This shows that the learning objectives have been achieved.

The average percentage of total positive responses of students at the disseminate stage was $94.11 \%$, so it can be concluded that the students' responses to the components and learning activities were very positive. Furthermore, the learning time used also meets the specified criteria.

Improvement of students' mathematical reasoning abilities is also evident from the data obtained at this stage, students who received an $\mathrm{N}$-gain score in the range $\mathrm{g}>0.7$ or experienced an increase in mathematical reasoning abilities with the "High" category by 12 students, there were 18 students experiencing increased abilities mathematical reasoning with the category "Medium" or get an $\mathrm{N}$-gain score in the range of $0.3<\mathrm{g} \leq 0.7$ and 5 students have increased mathematical reasoning abilities in the "Low" category. "Or get an N-gain score of $g \leq$ 0.3. The average total at the distribution stage was 0.57 in the medium category. Based on the data obtained on the achievement of students' self-confidence at the most dominant stage of the spread is the high and very high categories, which shows that students at this stage have high self-confidence.

The practicality of the learning device can be seen based on the analysis results of the trial I, trial II and the disseminate stage. A summary of the results of observations of the implementation of mathematics learning with the Visualization, Auditory, Kinesthetic (VAK) model at each stage can be seen in the following table:

Table 2. The Summary of Observations on the Implementation of Mathematics Learning

\begin{tabular}{|c|c|}
\hline Stage & $\begin{array}{c}\text { Percentage Average } \\
\text { Implementation of Learning }\end{array}$ \\
\hline Trial I & $85.53 \%$ \\
\hline Trial II & $91.40 \%$ \\
\hline Disseminate & $92.78 \%$ \\
\hline
\end{tabular}

Based on table 2 above shows that the average percentage of the feasibility of learning in trial I was $85.53 \%$, in trial II it was $91.40 \%$ and in the disseminate stage it was $92.78 \%$. Thus it can be concluded that the implementation of learning at each stage has met the practical criteria and is in the good category $(80 \leq \mathrm{k}<90)$.

The effectiveness of learning devices can be seen based on the analysis results of the trial I, trial II and the disseminate stage. The description of the results of students' mathematical reasoning ability can be seen in the 
following table:

Table 3. Description of Results of Mathematical Reasoning Capabilities

\begin{tabular}{|c|c|c|c|}
\hline Score & Trial I Posttest & Trial II Posttest & Disseminate Posttest \\
\hline \hline Highest Score & 93.75 & 93.75 & 100.00 \\
\hline Lowest Score & 50.00 & 62.50 & 62.50 \\
\hline Average & 76.43 & 83.04 & 88.75 \\
\hline
\end{tabular}

Based on the table 3 above shows that the results of the posttest analysis of the mathematical reasoning ability of the trial II students and the disseminate stage have met the classical completeness criteria. This is because learning materials and contextual problems that exist in student book and student activity sheet are developed in accordance with the characteristics of students who have previously had to solve a mathematical problem based on student knowledge gradually in line with continuous experience and increasing understanding of the information they find. This is in accordance with Piaget's learning theory (Setiawan et al. 2015) students of any age are actively involved in the process of obtaining information and constructing their knowledge. Surya et al (2017) states in the contextual implementation of learning the teacher needs to consider the cognitive development of students because of the child's mindset will be different from the mindset of adults.

By applying the Visualization, Auditory, Kinesthetic (VAK) model, students will be actively involved in the problem solving process. Students analyze and evaluate their own thought processes and make inferences from knowledge through social interactions with their environment that have been discovered by scaffolding from the teacher in the form of leading questions. This is reinforced by the view of Vygotsky (Arends. 2008) that social interaction with others both teachers and peers can be refer to the construction of new ideas and enhance students' intellectual development. Furthermore, Vygotsky (Trianto 2009) also revealed that with the provision of assistance (scaffolding) by teachers in the early stages of learning and reducing the assistance as they complete their assignments, the more active students will handle their learning tasks which will result in more effective learning which is done and has an impact on classical student completeness. In addition, completeness learning students are also influenced by student interaction with their environment. According to the Gestalt view (Hidayati 2011) through interaction will be formed perceptions, imaginations and new views that shape understanding (insight).

Completeness learning students are also influenced by the learning model used in the learning process, namely the Visualization, Auditory, Kinesthetic (VAK) model that makes students interested in learning and actively involved in the learning process. A similar sentiment was also stated by Ulia \& Sari (2018) in their research that students' activeness attitudes after getting lessons with the Visual Auditory Kinesthetic cooperative learning model had a positive impact. Correspondingly, Rahayu \& Ana (2017) said that the average student learning outcomes obtained through the VAK model are better than the average mathematics learning scores obtained through the direct approach.

Based on the analysis results of the achievement of the posttest learning objectives students' mathematical reasoning ability in the trial I was only achieved on 2 items, whereas the achievement of the posttest learning objectives the mathematical reasoning ability of the students in the trial II and disseminate stage had been reached for each item. Achievement of learning objectives by using learning material with the Visualization, Auditory, Kinesthetic (VAK) model because learning is carried out using material and contextual problems that are close to student life so that the material and contextual issues can be reached by students' imagination which makes students easier to find various possible solutions by doing mathematical modeling and solving these contextual problems with the model found. This is relevant to Bruner's theory, because at the beginning of learning students do activities such as observing the environment or using knowledge from previous observations in the learning process (enactive stage).

Based on the analysis data results of the trial I, trial II and the disseminate of distribution it was found that the average percentage of student responses in each trials was positive, meaning that overall students felt helped and pleased with the learning material developed with the Visualization, Auditory, Kinesthetic (VAK) model. Student responses given at each trials have reached predetermined criteria that is $\geq 80 \%$. This shows that the learning material developed using the Visualization, Auditory, Kinesthetic (VAK) model have met the effective criteria. Accordingly, the results of research by Daryanto (2007) states that the actions or responses taken by students are the result of interactions with the environment. This is because the learning process is a complex matter, where students determine whether they will learn or not. In addition, the positive response given by students is inseparable from several factors, one of which is the application of learning material with the Visualization, Auditory, Kinesthetic (VAK) model in the learning process. Learning by using learning material with Visualization, Auditory, Kinesthetic (VAK) model is meaningful learning that integrates students so that students are interested in learning, actively involved in the learning process, and responds positively to the learning material used.

Achievement of learning time with the Visualization, Auditory, Kinesthetic (VAK) model meets the effectiveness criteria. This is because learning takes place by linking material and contextual problems that are appropriate to the characteristics of students so students are active in the learning process and teachers can use 
time as effectively as possible for the success of the learning process. As stated by Slavin (2006) that the length of time given to students to learn the material presented is something that must be thought by the teacher because learning will spend a lot of time. The same thing was stated by Yuliani \& Saragih (2015) in their research that the study learning time used must refer to the usual learning time criteria, so that the learning time must be planned by the teacher in order to create effective and efficient learning.

Improvement of students 'mathematical reasoning abilities can be seen based on the N-Gain calculation of the results of students' mathematical reasoning tests in the trial I, trial II and the disseminate shown in the following graph.

Graph 1. Improvement of students 'mathematical reasoning ability from the N-gain scores

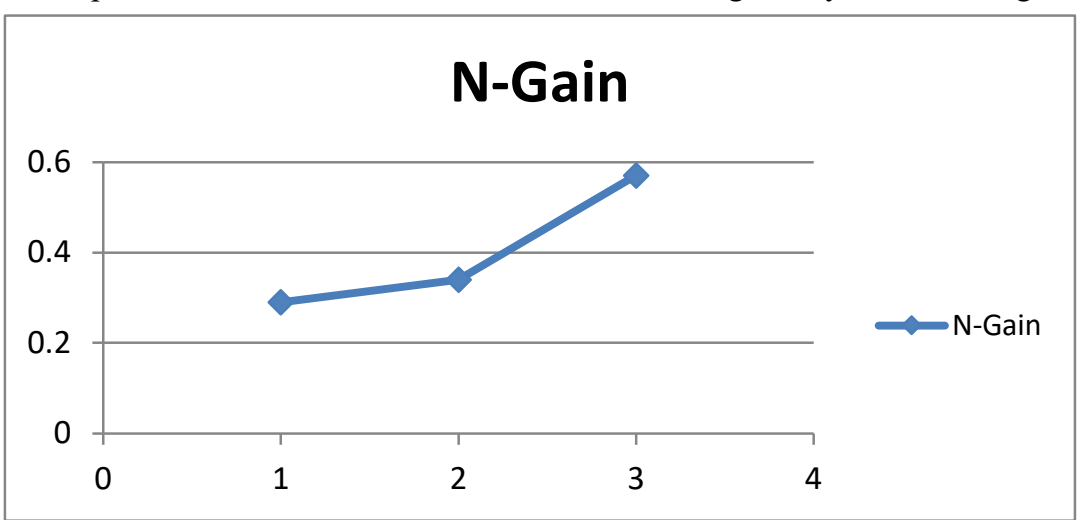

Based on graph 1 it can be seen that the test results of students 'mathematics reasoning ability in the trial I, trial II and disseminate stage showed that there was an improvement in students' mathematics reasoning ability from the $\mathrm{N}$-gain scores obtained. In the trial I, the $\mathrm{N}$-gain score obtained was 0.29 , in the trial II it increased to 0.34 and in the disseminate stage it increased to 0.57. Improving students' mathematical reasoning abilities due to the learning process using learning material with the Visualization, Auditory, Kinesthetic (VAK) model begins with contextual problems, so students can use their previous experience in understanding and solving mathematical problems. Contextual problems are designed so that the learning process is more meaningful, so that it can be understood that the contextual problem given can be used as a starting point in developing students' mathematical reasoning abilities. Furthermore the discussion conducted by students is a bridge of mutual help between students in understanding contextual problems. This is in line with Ausubel's theory (Trianto 2011), meaningful learning is a process of relating new information to relevant concepts contained in a person's cognitive structure. In meaningful learning the learning process starts from contextual problems and the information construction process occurs. In other words, a knowledge will be meaningful for students if the learning process involves real problems by being implemented in a context.

Based on the results of the questionnaire self-confidence data analysis of students in the trial I, trial II and the disseminate stage showed that there was an increase in student self-confidence. It can be seen from the average results of self-confidence questionnaires filled by students. The total score of the average score of the questionnaire self-confidence students in the trial I was 75.91 , increasing to 78.77 in the trial II and the disseminate stage increased to 79.97. This shows that the use of learning material developed with Visualization, Auditory, Kinesthetic (VAK) model has an impact on increasing students' self-confidence.

\section{Conclusion}

.Based on the results of the analysis and discussion in this study, it can be concluded that the learning material with the Visualization, Auditory, Kinesthetic (VAK) model have met the criteria of validity, practicality, and effectiveness as well as mathematical reasoning abilities and self-confidence students have increased. This research shows that learning material with the Visualization, Auditory, Kinesthetic (VAK) models are important to consider in an effort to maximize students' mathematics learning achievement. Thus, it is expected that mathematics teachers can apply mathematics learning using learning material with the Visualization, Auditory, Kinesthetic (VAK) model. It is recomended for for other researchers who will conduct research to measure students' mathematical reasoning ability so that they pay more attention to indicators draw conclusions, compile evidence, provide reasons or evidence for the correctness of the solution that is compiling evidence of contextual problems given in the form of mathematical models at its completion.

\section{References}

Anwar, K. (2016). Panel Discussion and the Development of Students' Self Confidence. English Language Teaching. Vol. 9 No. 4. ISSN: 1916-4742.

Arends, R.I. (2008). Learning To Teach Buku Dua. Edisi Ketujuh. Yogyakarta: Pustaka Pelajar 
Burton, K \& Platts, B. (2006). Building Confidence For Dummies. England: John Wiley \& Sons.

Daryanto. (2010). Belajar dan Mengajar. Bandung: Yrama Widya.

Depdiknas. (2008). Panduan Pengembangan Bahan Ajar. Direktort Pembinaan Sekolah Menengah Atas.

Hake, R. (1999). Analyzing Change/Gain Scores. Woodland Hills: Dept, of Physcis, Indiana University.

Hasratuddin. (2018). Mengapa Harus Belajar Matematika?. Medan: Penerbit Perdana Publishing.

Herman. (2012). Pengembangan Perangkat Pembelajaran Model Pengajaran Langsung untuk Mengajarkan Materi Kesetimbangan Benda Tegar. Jurnal Sains dan Pendidikan Fisika, (Online), Jilid 8 Nomor 1, April 2012 hlm 1-11, (http://digilib.unm.ac.id/download.php?id=236).

Hidayati, T.N. (2011). Implementasi Teori Belajar Gestalt. Jurnal FALASIFA. Bol. 2 No. 1

Islamiyah, A.C., Prayitno, S \& Amrullah. (2018). Analisis Kesalahan Siswa SMP Pada Penyelesaian Masalah Sistem Persamaan Linier Dua Variabel. Jurnal Didaktik Matematika

Juliana, M. dan Surya, E. (2017). An Analysis Of Jigsaw Cooperative Effectiveness to Improve the Sel-Confidence and Learning Result of Vocational High School Students. International Journal of Advanced Research and Innovative Ideas in Education. ISSN: 2395-4396, Vol 3.

Kilpatrick, J. Swafford, J. \& Findell, B. (2001). Adding It Up: Helping Children Learn Mathematics. Washington, DC: National Academy Press.

Lestari, K.E \& Yudhanegara, M.R. (2015). Penelitian Pendidikan Matematika. Bandung: PT: Refika Aditama.

Makonye, J.P. (2014). Teaching Function Using a Realistic Mathematics Education Approach : A Theoretical Perspective. International Journal Education Science 7(3): 653-662.

Misnanti, Utami, R.W, \& Suwanto, F.R. (2017). Problem Based Learning to Improve Proportional Reasoning of Students in Mathematics Learning. The 4th International Conference on Research, Implementation, and Education of Mathematics and Science (4th ICRIEMS).

Napitupulu, E.E., Suryadi, D, dan Kusumah, Y.S. (2016). Cultivating Upper Secondary Students' Mathematical Reasoning-Ability and Attitude Towards Mathematics Through Problem- Based Learning. Journal on Mathematics Education. Vol 7, No 2, pp 61-71.

Nurqolbiah, Sofi. (2016). Peningkatan Kemampuan Pemecahan Masalah, Berpikir Kreatif Dan Self-Confidence Siswa Melalui Model Pembelajaran Berbasis Masalah. Jurnal Penelitian Pendidikan dan Pengajaran Matematika. Vol. 1 No. 3, hal. 225-240

Rahayu, S. \& Ana. (2017). Pembelajaran Matematika Melalui Pendekatan Kontekstual Dengan Gaya Belajar VAK (Visual Auditory Kinestetik). Jurnal Edumath, 3(2), 129-137.

Reddy, M. M. (2014). A Study of Self Confidence in Relation to Achievement Motivation of D.ed Students. Global Journal for Research Analysis. Tirupati: GJRA. Volume 3, Issue 8, ISSN No 2277-8160.

Rizqi, N.R and Surya, E. (2017). An Analysis of Students' Mathematical Reasoning Ability in VII Grade of Sabilina Tembug Junior High School. International Journal Of Advances Research and Innovative Ideas in Edducation (IJARIIE). ISSN: 2395-4396.

Rohana. (2015). The Enhancement of Student's Teacher Mathematical Reasoning Ability Through Reflective Learning. Journal of Education and practice. Vol 6 No 20.2015

Saputri, L. \& Sari, D.P. (2017). Peningkatan Kemampuan Refresentasi Matematis Melalui Model Pembelajaran Visualization Auditory Kinesthetic (VAK) Berbantuan Wingeom Pada Mata Kuliah Geometri Transformasi di STKIP Budidaya Binjai. Jurnal PARADIKMA. Vol. 10 No. 2

Setiawan, A., Jamal, M.A., \& Suriasa. (2015). Optimalisasi Hasil Belajr Siswa Melalui Penerapan Model Pembelajaran Kooperatif Tipe VAK (Visual, Auditory, Kinestetik). Berkala Ilmiah Pendidikan Fisika Vol 3 No 2 .

Shoimin, A. (2016). 68 Model Pembelajaran Inovatif dalam Kurikulum 2013. Yogyakarta: Ar-Ruzz Media

Sihotang, L., Setiawan, D., dan Saragih, D. (2017). The Effect of Learning Strategy and Self Confidence Toward Student's Learning Outcomes in Elementary School. IOSR Journal of Research \& Method in Education (IOSR-JRME).

Slavin, R. E. (2006). Educational Psychology, Theories and Practice. Eighth Edition. Masschusetts: Allyn and Bacon Publishers.

Subanindro. (2012). Pengembangan Perangkat Pembelajaran Trigonometri Berorientasikan Kemampuan Penalaran dan Komunikasi Matematik Siswa SMA. Seminar Nasional Matematika dan Pendidikan Matematika FMIPA UNY. ISBN: 978-979-16353-8-7.

Suhadi. (2007). Petunjuk dan pedoman pembelajaran. Surakarta: Universitas Muhamadiyah

Sumartini, T.S. (2015). Peningkatan Kemampuan Penalaran Matematis Siswa Melalui Pembelajaran Berbasis Masalah. Jurnal Pendidikan Matematika. Volume 5, Nomor 1

Surajiyo. (2010). Filsafat Ilmu dan Perkembangan di Indonesia. Jakarta: PT Bumi Aksara

Surya, E., Putri, F.A. \& Mukhtar. (2017). Improving Mathematical Problem-Solving Ability and Self-Confidence Of High School Studets Throught Contextual Lerning Model. Journal On Matehmatical Education. ISSN 2087-8885 
Thiagarajan, S., Semmel, D.S., \& Semmel, M.I. (1974). Instructional Development for Training Teacher of Exeptional Children: A Sourcebook. Indiana: Indiana University

Trianto. (2009). Mendesain Model Pembelajaran Inovatif-Progresif. Jakarta: Kencana.

Trianto. (2011). Model-Model Pembelajaran Inovatif Berorientasi Konstructivisme. Jakarta: Prestasi Pustaka.

Tuncel, H. (2015). The relationship between self-confidence ad learning Turkish as a foreign language. Educational Research and Reviews. ISSN: 1990-3839.

Turkkahraman, M. (2012). The Role Of Education In The Societal Development. Journal of Educational and Instructional Studies. Vol.2. ISSN: 2146-7463.

Ulia, N \& Sari, Y. (2018). Pembelajaran Visual, Auditory dan Kinestetik Terhadap Keaktifan dan Pemahaman Konsep Matematika Siswa Sekolah Dasar. Jurnal Pendidikan Guru MI. ISSN: 2442-5133.

Yuliani, K \& Saragih, S. (2015). The Development of Learning Devices Based Guided Discovery Model to Improve Understanding Concept and Critical Thinking Mathematically Ability of Student at Islamic Junior High School of Medan. Journal of Education and Practice IIST. Vol. 6, No.24:116-128.

Zuhdan, Kun \& Tim. (2011). Pengembangan Perangkat Pembelajaran Sains Terpadu untuk Meningkatkan Kognitif, Keterampilan Proses, Kreativitas serta Menerapkan Konsep Ilmiah Peserta Didik SMP. Yogyakarta: UNY

Zulfa, F.S, Yerizon, \& Amalita, N. (2014). Pengaruh Penerapan Metode Penemuan Terbimbing Terhadap Kemampuan Penalaran matematis Siswa Kelas XI IPA SMAN 1 Padang Panjang. Jurnal Pendidikan Matematika. Vol. 3 No. 3. 